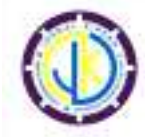

e-ISSN: 2580-6947

p-ISSN: 2354-7278

http://ojs.umrah.ac.id/index.php/kiprah/index

\title{
ANALISIS KESALAHAN SISWA DALAM MENYELESAIKAN SOAL TENTANG MEMBACA DENAH
}

\author{
Anugrah Perkasa*, Nur Izzati
}

Universitas Maritim Raja Ali Haji, Kota Tanjungpinang, Kepulauan Riau 29115, Indonesia

\begin{abstract}
Abstrak
Membaca denah merupakan sub materi pada topik Skala pada pelajaran matematika di SD yang dalam materi pembelajarannya tidak selalu mengharuskan siswa untuk menghitung, namun menuntut kemampuan menalar atau berpikir kritis. Membaca denah memerlukan ketelitian dan pemahaman menganalisa dari siswa. Pada kenyataannya masih banyak siswa yang melakukan kesalahan dalam menyelesaikan soal tentang membaca denah. Penelitian ini bertujuan untuk menganalisis jenis kesalahan siswa dalam menyelesaikan soal membaca denah tersebut. Jenis penelitian ini berupa deskriptif eksploratif kualitatif dengan subjeknya terdiri dari 15 siswa kelas $\mathrm{V}$ SD Muhammadiyah Tanjungpinang. Pengumpulan data dilakukan melalui tes tertulis dan wawancara. Teknik analisis data mengacu pada model Miles dan Huberman. Penelitian dilakukan dengan cara memberikan 3 nomor soal untuk sebuah denah dalam bentuk uraian. Hasil penelitian menunjukkan terdapat dua kesalahan utama siswa yaitu kesalahan konseptual dan kesalahan prosedural. Kesalahan konseptual meliputi: (1) Kesalahan menganalisa konsep membaca denah; (2) Kesalahan menyebutkan arah mata angin pada denah; (3) Kesalahan memersepsikan denah. Sedangkan kesalahan prosedural meliputi: (1) kesalahan menentukan arah jalan pada denah, dan; (2) kesalahan memaknai soal.
\end{abstract}

Kata Kunci: analisis kesalahan, kesalahan konseptual dan prosedural, membaca denah

\section{PENDAHULUAN}

Pelajaran matematika sejatinyanya merupakan sebuah ilmu pasti yang menjadi dasar atau rujukan dari ilmu lain, sehingga matematika sering disebut sebagai ibu dari ilmu pengetahuan. Di mana, pelajaran matematika dikhususkan pada perhitungan angka-angka yang didasari oleh rumus-rumus yang telah ada. Pelajaran matematika menekankan siswa untuk paham konsep dalam mempelajarinya. Muhsetyo (2008), juga menyatakan hal senada, bahwa pembelajaran matematika adalah proses pemberian pengalaman belajar kepada peserta didik melalui serangkaian kegiatan yang terencana sehingga peserta didik memeroleh kompetensi tentang bahan matematika yang dipelajari. Oleh karenanya, pelaku pendidikan dalam hal ini harus mampu menerapkan strategi yang ampuh dalam mengajarkannya. Selain itu, matematika juga merupakan pelajaran yang mendorong peserta didik untuk berpikir cerdas dan logis.

Skala merupakan salah satu materi pelajaran matematika di Sekolah Dasar (SD) khususnya di kelas V (lima) yang dalam sub bab pembelajarannya tidak selalu mengharuskan siswa untuk menghitung, tetapi juga kemampuan menalar atau berpikir kritis. Sub bab materi yang dimaksud adalah materi tentang denah. Halpen (dalam Achmad, 2007), menyatakan bahwa berpikir kritis adalah memberdayakan ketrampilan atau strategi kognitif dalam menentukan tujuan. Berbicara tentang denah, sangat erat kaitannya dengan skala. Denah adalah gambar yang menunjukan letak suatu tempat atau benda. Pada pembelajaran mengenai denah ini peserta didik diminta untuk memiliki kemampuan intelektual berpikir kritis tingkat tinggi, agar bisa membaca arah denah.

Pusat Pengembangan Kurikulum dan 
Sarana Pendidikan Badan Penelitian dan Pengembangan (Depdikbud, 1999), menyatakan bahwa perbandingan dan skala adalah salah satu topik yang tergolong mudah untuk diajarkan karena hanya membutuhkan pemahaman. Akan tetapi, data di lapangan menunjukan bahwa masih banyak siswa yang salah mengerjakan soal-soal tentang denah ini, padahal soal tersebut hanya mengharuskan mereka untuk menganalisa dan berpikir logis dan kritis dalam menyelesaikannya. Kesulitan dan kesalahan yang terjadi disebabkan oleh siswa tidak memahami konsep.

Kesalahan yang dilakukan siswa dalam menyelesaikan soal membaca arah denah dialami diberbagai SD/MI, termasuk di SD Muhammadiyah Tanjungpinang. Hal ini diketahui setelah peneliti melakukan proses pembelajaran mengenai materi tersebut. masih banyak siswa yang belum mengerti dengan konsep arah mata angin dalam membaca denah. Agar dapat mengetahui lebih jauh tentang kesalahan-kesalahan siswa dalam menyelesaikan soal tentang membaca denah maka perlu dilakukan suatu penelitian.

Berdasarkan uraian di atas, dapat dikemukakan rumusan masalah penelitian ini, yaitu: "Apa saja jenis kesalahan yang dilakukan siswa dalam meyelesaikan masalah soal tentang denah di kelas $\mathrm{V} \quad \mathrm{SD}$ Muhammadiyah Tanjungpinang?"

Tujuan dari penelitian ini adalah untuk mendeskripsikan jenis-jenis kesalahan dilakukan siswa dalam menyelesaikan soal tentang membaca denah di kelas V SD Muhammadiyah Tanjungpinang.

\section{METODE}

Jenis penelitian ini adalah penelitian kualitatif dengan metode deskriptif eksploratif. Penelitian ini dilaksanakan di SD Muhammadiyah Kota Tanjungpinang dengan subjek penelitian adalah siswa kelas V Tahun Pelajaran 2018/2019. Subjek yang dipilih sebagai informan yaitu 3 siswa dari 15 siswa berdasarkan pertimbangan-pertimbangan berikut: 1) kesalahan siswa bervariasi, 2) kemampuan siswa berkomunikasi dengan baik dan 3) kesediaan siswa menjadi subjek informan. Penelitian dilakukan melalui beberapa tahapan, mulai dari pengamatan awal terhadap kemampuan siswa, pemberian tes tertulis, hingga melakukan wawancara untuk mendapatkan data.

Teknik pengumpulan data meliputi tes tertulis dan wawancara. Instrumen pada penelitian ini adalah instrumen tes tertulis dan pedoman wawancara. Teknik pemeriksaan keabsahan data yang digunakan yaitu metode triangulasi. Metode Triangulasi dilakukan untuk mencari kesesuaian data hasil tes dan wawancara. Analisis data mengacu pada model Miles dan Huberman (Sugiyono, 2009) yaitu reduksi data, penyajian data dan penarikan kesimpulan.

\section{HASIL DAN PEMBAHASAN Hasil Penelitian}

Peneliti memberikan tes tentang membaca atau menentukan arah denah kepada 15 siswa kelas V SD Muhammadiyah Tanjungpinang. Tes yang diberikan terdiri atas 3 soal untuk sebuah denah sebagaimana ditunjukan pada Gambar 1. Berdasarkan kriteria yang telah ditetapkan pada metode penelitian, maka subjek yang terpilih sebagai informan dalam penelitian ini adalah LHA, ZF dan BR. Setiap subjek informan mewakili satu kesalahan jawaban penyelesaian.

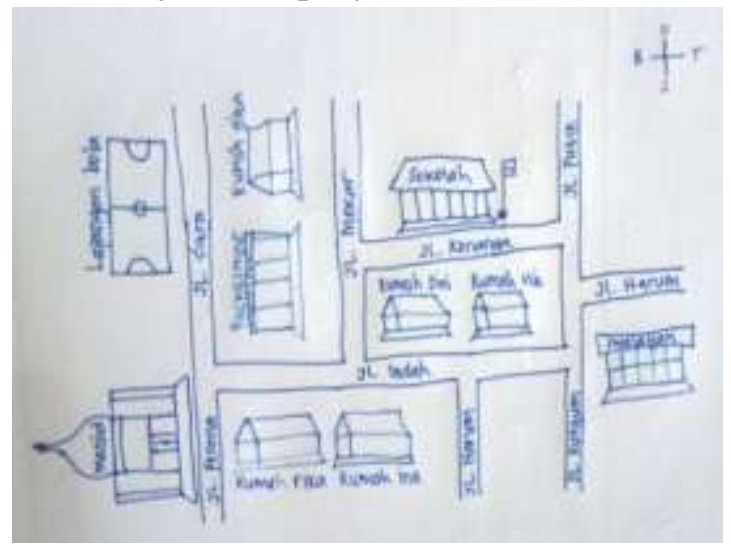

Gambar 1. Denah untuk Soal

Pertanyaan:

1. Di manakah letak puskesmas jika dilihat dari rumah Gita?

2. Jalan manakah yang sama-sama dilewati Via jika hendak pergi ke masjid atau lapangan bola?

3. Rika hendak pergi ke sekolah bersama Ina, jalan manakah yang terdekat yang harus dilaluinya setelah menjemput Ina? 
Berdasarkan hasil dari tes tersebut, diketahui 3 orang siswa menjawab salah untuk soal nomor 1, 9 orang menjawab salah untuk soal nomor 2 dan 8 orang menjawab salah untuk soal nomor 3 .

\section{Pembahasan}

Untuk jawaban soal nomor 1 peneliti mengambil informan ZF, karena kesalahan penyelesaian yang dilakukan dapat mewakili kesalahan siswa lain yang juga salah pada soal tersebut. Jawaban ZF terhadap soal nomor 1 disajikan pada Gambar 2.

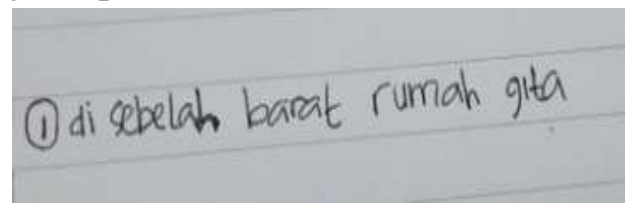

$$
\text { ZF menjawab soal dengan }
$$
memperkirakan bahwa bentuk gambar rumah pada denah itu mempengaruhi arah mata angin. Padahal dalam konsep membaca denah patokan atau acuan utama kita adalah arah mata angin yang dikasi atau diberikan pada denah tersebut. ZF melihat bahwa rumah digambarkan vertikal, dan dia mungkin mengira bahwa arah mata angin juga berubah sesuai gambar. Sehingga dia menjawab puskesmas itu berada disebelah barat rumah Gita. Jawaban yang benar adalah di sebelah selatan rumah Gita.

Peneliti melakukan wawancara untuk memperoleh informasi lebih lanjut tentang kesalahan ZF yaitu di sebelah barat rumah gita. Berikut petikan dialog wawancara dengan ZF yang telah direduksi.

Peneliti : "Dari denah ini, coba ZF jelaskan ke Bapak kenapa ZF bisa menjawab seperti jawaban dilembar jawaban ZF nak?”

ZF : "Saya lihat dari gambarnya rumah Gita pak, kan kalau dari gambar nampaknya puskesmas itu di Barat rumah Gita, Pak."

Peneliti : "Apakah ZF tidak melihat tanda
arah mata angin di denah
tersebut?"

\section{ZF : "Lihat Pak."}

Peneliti : "Apakah sesuai arah mata angin pada peta dengan jawaban ZF?"

ZF

$$
\begin{aligned}
& \text { : "Sesuai Pak kalau dilihat dari } \\
& \text { gambar rumah Gita." }
\end{aligned}
$$

Berdasarkan hasil tes dan wawancara yang dilakukan pada ZF untuk kesalahan yang dilakukannya untuk menjawab soal nomor 1 diperoleh informasi atau dugaan bahwa ZF menganggap dalam membaca denah yang diperhatikan itu bukan letak arah mata angin pada denah itu, tetapi bagaimana gambar denah itu disajikan sehingga ZF salah menyebutkan arah mata angin tersebut. kesalahan yang dilakukan ZF yaitu kesalahan menganalisa denah. Selain itu juga kasus ZF ini termasuk dalam kesalahan memersepsikan denah.

Subjek penelitian yang dipilih sebagai informan untuk soal nomor 2 adalah LHA, karena kesalahan yang dilakukan dapat mewakili kesalahan yang dilakukan oleh yang lain. Jawaban LHA untuk soal nomor 2 dapat dilihat pada Gambar 3.

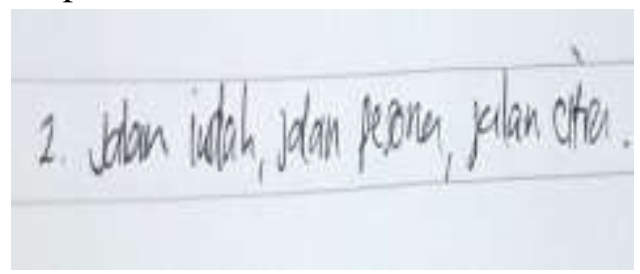

Gambar 3. Jawaban LHA

Dalam menjawab soal nomor 2 ini, informan LHA menjawab dengan pengertian soal yang dia pahami. Sehingga untuk pertanyaan soal nomor dua itu dia menjawab jalan yang dilewati Via ialah jalan Indah, jalan Pesona dan jalan Citra. LHA melihat semua jalan yang dilewati oleh Via untuk menuju ke masjid dan lapangan sepak bola. Padahal, yang ditanya itu jalan mana yang tetap atau samasama dilewati Via jika hendak pergi ke masjid atau lapangan bola. Jawaban yang benar ialah jalan Indah.

Untuk mendapatkan informasi lebih jelas mengenai jawaban LHA terkait soal nomor 2, peneliti melakukan tes wawancara. Berikut 
Petikan dialog wawancara dengan LHA yang telah direduksi.

Peneliti : "Coba jelaskan kepada Bapak jawaban yang LHA dapatkan ini."

LHA : "Saya menjawab dengan melihat jalan mana saja yang dilewati Via Pak."

Peneliti : "Apakah menurut LHA jawaban yang LHA tulis itu sudah sesuai dengan maksud soal?"

LHA : "InsyaAllah Pak, kan yang ditanya jalan yang dilewat."

Berdasarkan hasil wawancara, dapat peneliti simpulkan bahwa kesalahan yang dilakukan oleh LHA berupa kesalahan menetukan arah jalan dan kesalahan memaknai soal. LHA belum memahami tentang maksud yang dikehendaki soal. Hal inilah yang menyebabkan LHA melakukan kesalahan menjawab soal nomor 2 .

Selanjutnya, kesalahan jawaban soal nomor 3, seperti ditunjukkan oleh Gambar 3. Subjek yang dipilih sebagai informan untuk soal nomor 3 ini ialah BR.

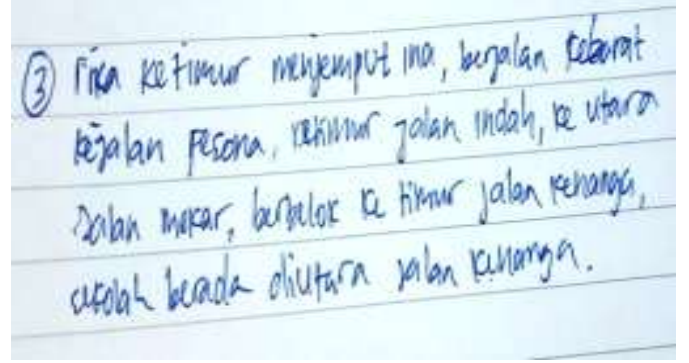

Gambar 3. Jawaban BR

BR menjawab soal nomor 3 ini sebenarnya sudah hampir benar, hanya saja terdapat beberapa kekeliruan dalam bahasa mendeskripsikan jawaban dari soal nomor 3 . Selain itu, BR sepertinya juga belum mengerti apa yang diminta oleh soal. Hal ini terbukti pada jawaban BR yang menyatakan: "...berbelok ke barat jalan Pesona", setelah menjemput Ina, dia berbalik lagi ke jalan Pesona. Tentunya ini akan memperlama perjalanan mereka. Sedangkan soal meminta jalan terdekat yang dilalui untuk sampai ke sekolah. Disinilah letak salahnya jawaban BR yang hampir sama dengan teman-temannya yang melakukan kesalahan pada soal nomor 3 . Jawaban yang benar ialah Rika berjalan ke timur dari rumahnya untuk menjemput Ina, kemudian mereka berjalan ke arah utara melalui jalan Harum, dan berbelok ke barat Jalan Indah, lalu lurus ke utara melalui Jalan Mekar dan berbelok ke timur Jalan Kenanga, sekolah berada di utara Jalan Kenanga.

Tes wawancara dilakukan oleh peneliti untuk mengetahui atau mendapatkan informasi lebih lanjut tentang kesalahan menjawab soal yang dilakukan oleh BR. Berikut petikan dialog wawancara dengan BR yang telah direduksi.

Peneliti : "Coba jelaskan jawaban yang telah BR peroleh Nak."

BR : "Pada soalkan menyatakan Rika ke sekolah menjemput Ina dulu, ya saya tulis seperti itu, kemudian saya tulis seтиa jalan yang dilalui mereka untuk sampai ke sekolah."

Peneliti : "Apakah menurut BR, jawaban itu sesuai dengan yang diminta soal?"

BR : "Iya pak."

Peneliti : "Apakah itu jalan terdekat untuk mereka sampai ke sekolah?”

Peneliti : "Hem,, sepertinya iya Pak."

Berdasarkan hasil wawancara dengan $\mathrm{BR}$, peneliti dapat mengambil kesimpulan bahwa sebenarnya BR sudah paham konsep mengenai denah ini. Akan tetapi, ada beberapa kesalahan yang terjadi dalam menjawab soal. BR belum bisa membedakan mana jalan terdekat yang bisa dilewati untuk mencapai kesekolah. Kesalahan yang terjadi pada jawaban soal nomor 3 BR ialah kesalahan memersepsikan denah, kesalahan menganalisa konsep membaca denah, kesalahan menetukan arah jalan dan kesalahan mengartikan soal.

Berdasarkan analisis data hasil tes dan hasil wawancara, diperoleh kesalahankesalahan yang dilakukan oleh siswa dalam menyelesaikan soal tentang denah yaitu kesalahan konseptual dan kesalahan prosedural. Kesalahan-kesalahan siswa yang 
JURNAL KIPRAH, Desember 2018; V1(2): 48-53

e-ISSN: 2580-6947

p-ISSN: 2354-7278

ditemukan pada penelitian ini disajikan pada Tabel 1.

Tabel 1.

Kesalahan Siswa dalam Mengerjakan Soal

\begin{tabular}{|c|c|c|c|c|c|c|}
\hline \multirow{2}{*}{$\begin{array}{l}\text { No } \\
\text { Soal }\end{array}$} & \multirow{2}{*}{$\begin{array}{c}\text { Subjek } \\
\text { sebagai } \\
\text { Informa } \\
\mathrm{n}\end{array}$} & \multicolumn{3}{|c|}{$\begin{array}{l}\text { Kesalaha } \\
\mathrm{n} \\
\text { konseptu } \\
\text { al }\end{array}$} & \multicolumn{2}{|c|}{$\begin{array}{l}\text { Kesalahan } \\
\text { Prosedural }\end{array}$} \\
\hline & & A & B & $\mathrm{C}$ & $\begin{array}{l}\text { Arah/Na } \\
\text { ma Jalan }\end{array}$ & $\begin{array}{c}\text { Memaha } \\
\text { mi } \\
\text { soal }\end{array}$ \\
\hline 1 & $\mathrm{ZF}$ & $\sqrt{ }$ & $\sqrt{ }$ & $\sqrt{ }$ & & \\
\hline 2 & LHA & & & & $\sqrt{ }$ & $\sqrt{ }$ \\
\hline 3 & BR & $\sqrt{ }$ & & $\sqrt{ }$ & $\sqrt{ }$ & $\sqrt{ }$ \\
\hline & nlah & 2 & 1 & 2 & 2 & 2 \\
\hline
\end{tabular}

Keterangan:

$\mathrm{A}=\quad$ Kesalahan menganalisa konsep membaca denah

$\mathrm{B}=$ Kesalahan menyebutkan arah mata angin pada denah

$\mathrm{C}=$ Kesalahan memersepsikan denah

Kesalahan konseptual yang ditemukan

dalam penelitian ini adalah kesalahan menganalisa konsep membaca denah, kesalahan menyebutkan arah mata angin pada denah, kesalahan memersepsikan denah. Kesalahan menganalisa konsep membaca denah yang lakukan oleh ZF dan soal nomor 3 yang dilakukan oleh BR. Kesalahan siswa tersebut dikarenakan konsep-konsep yang terkait dengan materi membaca denah yang digunakan oleh siswa merupakan konsep yang salah. Sejalan dengan itu Widodo (2013) menyatakan bahwa kesalahan konsep adalah kesalahan dalam menggunakan konsep-konsep yang terkait dengan materi.

Kesalahan konseptual selanjutnya ialah kesalahan dalam menyebutkan arah mata angin sebagai petunjuk dalam membaca denah. Kesalahan menyebutkan arah mata angin ini dilakukan oleh ZF pada soal nomor 1. ZF tidak memahami penggunaan arah mata angin dalam denah, sehingga arah jalan yang disebutnya salah. Kesalahan-kesalahan tersebut dikarenakan siswa tidak dapat menggunakan aturan penggunaan arah mata angin dengan benar.

Kesalahan lain yang dialkukan siswa dan

masih termasuk dalam kesalahan konseptual ialah kekeliruan siswa dalam mengaitkan beberapa konsep atau beberapa fakta dalam menyelesaikan soal membaca denah atau dengan kata lain mempersepsikan denah. Kesalahan yang dilakukan siswa terdiri atas: (a) kesalahan melihat, menelaah dan membaca gambar denah dilakukan oleh ZF soal nomor 1. Kesalahan tersebut dilakukan siswa karena tidak memahami mengenai prinsip membaca denah. (b) kesalahan tentang penafsiran maksud soal yang dilakukan BR pada soal nomor 3.

Kesalahan prosedural yang dilakukan siswa dalam penelitian ini adalah kesalahan menentukan arah jalan dan kesalahan memaknai soal. Kesalahan menentukan arah jalan dilakukan oleh LHA pada soal nomor 2, dan BR pada soal nomor 3. Jawaban siswa tersebut pada soal nomor 2 dan nomor 3 salah karena mereka mengerjakan soal tidak memperhatikan arah/nama jalan serta belum mengerti cara membaca denah sehingga jawaban salah. Sebagaimana pendapat Lestari (2011) yang menyatakan bahwa penyebab kesalahan jawaban akhir siswa yang tidak sesuai apa yang diminta soal karena siswa tidak mengetahui caranya.

Kesalahan memaknai soal dilakukan oleh LHA dan BR pada soal nomor 2 dan 3. Kesalahan memaknai soal biasanya terjadi pada soal yang memiliki daya pengecoh dan tingkat yang tinggi. Selain itu, Kesalahan ini juga sering terjadi ketika seseorang belum sepenuhnya paham dengan konsep maupun pertanyaan soal. Sesuai dengan pernyataan Agrawal dan Gibson (1999), dalam bukunya ia menjelaskan bahwa persepsi (mengartikan soal) merupakan proses kognitif yang mana digunakan oleh seseorang untuk dapat menafsirkan serta memahami dunia yang ada di sekitarnya terhadap sebuah objek. Kesalahan persepsi terjadi ketika seseorang melakukan penafsiran tanpa dilandasi pengetahuan atas apa yang ditafsirnya tersebut.

Hasil penelitian ini mendukung hasil penelitian yang dilakukan oleh Suwarni. S (2017) dan Muarrafah, L (2018). Hasil 
penelitian Suwarni, S (2017) menunjukkan bahwa kesalahan siswa dalam mengerjakan soal kebanyakan berkaitan salah pada pemahaman konsep. Sementara menurut hasil penelitian Muarrafah, L (2018), kesalahankesalahan yang sering dilakukan siswa dalam mengerjakan soal biasanya terkait kesalahan kontekstual dan prosedural.

\section{KESIMPULAN}

\section{Kesimpulan}

Berdasarkan hasil penelitian dan pembahasan, dapat disimpulkan bahwa kesalahan-kesalahan yang dilakukan siswa dalam menyelesaikan soal tentang denah, secara garis besar dapat dikategorikan sebagai kesalahan konseptual dan kesalahan prosedural. Kesalahan konseptual meliputi kesalahan menganalisa konsep membaca denah, kesalahan menyebutkan arah mata angin pada denah, dan kesalahan memersepsikan denah. Sedangkan kesalahan prosedural meliputi kesalahan menentukan arah/nama jalan dan kesalahan memaknai soal. Saran

Berdasarkan hasil penelitian, Peneliti dapat memberikan saran kepada tenaga pengajar untuk mengurangi kesalahan siswa pada materi skala khususnya membaca denah, hendaknya: 1) Guru lebih memperdalam pemahaman konsep siswa terutama menentukan arah mata angin dalam membaca denah. 2) Siswa seharusnya dibiasakan untuk menyelesaikan soal dengan langkah-langkah penyelesaian yang lengkap seperti mendeskripsikan secara runtun infoermasi dari denah.

\section{DAFTAR PUSTAKA}

Achmad, A. 2007. Memahami Berpikir Kritis. [Online]. Tersedia: http://researchengines.com/1007rief3.ht ml [20 Januari 2013]

Agrawal, A. and Gibson C. 1999. Enhancement and Disenhancement: The Role of Community in Natural Resource Concervation. World Development. 27, (4), 629-649.

Lestari, R, D. 2011. Analisis Kesalahan Siswa dalam Menyelesaikan Soal Faktorisasi
Suku Aljabar pada Siswa Kelas VIII SMP Negeri 1 Jaten Tahun Ajaran 2010/2011. [Online]. Tersedia: http://perpustakaan.uns.ac.d.12351268.p df [23 Oktober 2017]

Muarrafah, L. 2018. Analisis Kesalahan Siswa SD dalam Menyelesaikan Soal Cerita Pecahan. Tesis pada Universitas Negeri Malang: Tidak diterbitkan.

Muhsetyo, G. 2008. Pembelajaran Matematika $S D$. Jakarta: UT.

Sugiyono. 2009. Memahami Penelitian Kualitatif. Bandung: Alfabeta.

Suwarni, S. 2017. Peningkatan Hasil Belajar Perbandingan dan Skala melalui Pembelajaran Matematika Realistik. Jurnal Riset dan Konseptual. 2, (1), 5865. [Online]. Tersedia: http://www.jurnal.unublitar.ac.id/index.p hp/briliant. [2 November 2018]

Widodo, S. A. 2013. Analisis Kesalahan dalam Pemecahan Masalah Divergensi Tipe Membuktikan pada Mahasiswa Matematika. Jurnal Pendidikan dan Pengajaran. 46, (02), 106-112. [Online]. Tersedia: http://download.portalgaruda.org/article. php?article $=145430 \& v a l=1324 \&$ title. [5 Juni 2017]. 
JURNAL KIPRAH, Desember 2018; V1(2): 48-53

e-ISSN: 2580-6947

p-ISSN: 2354-7278 